\title{
University Readiness to Online Education during Covid-19 Pandemic
}

\author{
Taylan Budur ${ }^{1} \&$ Ahmet Demir ${ }^{2} \&$ Fatih Cura $^{3}$ \\ ${ }^{1,2}$ Department of Business and Administration, Tishk International University, Sulaymaniyah, Iraq \\ ${ }^{3}$ Department of Business and Administration, Tishk International University, Erbil, Iraq \\ Correspondence: Taylan Budur, Tishk International University, Sulaymaniyah, Iraq \\ Email: taylan.budur@tiu.edu.iq
}

Doi: 10.23918/ijsses.v8i1p180

\begin{abstract}
The aim of the study is to develop a reliable evaluation criterion to assess the readiness of the education institutions for online education. In this regard, we adopted Lokuge et al. (2019) questionnaire to evaluate universities preparedness in Kurdistan Region of Iraq. Based on that, content analysis has been fulfilled with the academicians in the region. The results were analyzed through validity and reliability methodologies. Lastly, the independent samples t-test has been employed to compare the readiness of public and private universities in the region. Therefore, the prior aim of the current study was to develop a questionnaire to test the readiness of the universities for online education. Secondly, we aimed to test the questionnaire comparing the readiness of public and private universities. It was found that the adopted questionnaire worked properly in the education field. Therefore, the questionnaire can be used in all educational institutions. Secondly, there is a lack of study in the readiness for online education field after Covid-19. Hence, the current study develops a methodology to measure online education at the universities using a state of art questionnaire.
\end{abstract}

Keywords: Organizational Readiness, Organizational Change, Change Valance, Change Efficacy, Contextual Factors, Readiness Theory, University Readiness to Online Education, Covid-19 Pandemic, Innovation, Kurdistan, Iraq

\section{Introduction}

Digital education is an unavoidable alternative for academic institutions during the Covid-19 outbreak. In this regard, institutions should be aware of their responsibilities in terms of the aspirations of students to provide appropriate services in relation to the normal education period, while upgrading and introducing a new system in which they should not face any barriers. On the other hand, academic and non-academic staff should be trained to have efficient facilities and quality teaching capabilities. Further, the preparation of the university, faculty, and departments is crucial in delivering professional facilities to lecturers and students. In this respect, lecturers' preparation for apps, programs, or networks in which they communicate with students has a significant impact on both lecturers' and students' perceptions of online education. As a result, Martin et al. (2019) stated that, in addition to effective online class management, students need an online support desk where they can resolve connectivity or password issues in a timely manner (Gay, 2016).

Received: December 5, 2020

Accepted: February 19, 2021

Budur, T., Demir, A., \& Cura, F. (2021). University Readiness to Online Education during Covid-19 Pandemic. International Journal of Social Sciences and Educational Studies, 8(1), 180-200. 
Furthermore, Lichoro (2015) stated that unprepared instructors have negative effect on the student's perception about e-learning. Similarly, Downing and Dyment (2013) indicated that teachers perceive online education as time-consuming, which would have significant negative effect on the perception of the students, respectively. On the other hand, Cheon et al. (2012) revealed in their detailed study that students behavioral control variables are vitally important on their positive attitudes (e.g., theory of planned behavior; normative beliefs, subjective norms, and perceived behavior control). In this respect, it has been observed that sharing meaningful information, considering students levels by all phases, and providing user-friendly software have significant positive impact on the student's attitudes for further developments (Cheon et al., 2012).

Moreover, Lloyd et al. (2012) defined four types of barriers during the organizational change to adapt online education at university, which are interpersonal barriers, institutional barriers, training and technology barriers, and cost/benefit barriers. Accordingly, they noted that being aware of such kinds of problems, facilitate the adaptation process of the faculties and lecturers to new system and structure (Lloyd et al., 2012). Additionally, they indicated that experience of the faculty and lecturer with distance education is the key factor to cope with the barriers for the effectiveness of the online education system. Similarly, Cheon et al., (2012) revealed that faculty members' participation to strategic plans by the implementation of online learning increase the success of the process. In this respect, Buckenmeyer et al. (2011) and Cutri and Mena (2020) stated the importance of the faculty members willingness for online education that positively enhance competitive advantage in the market.

In line with this, Martin et al. (2019) argued that lecturers experience has significant impact on the effectiveness of the online education. Further, researchers noted that the success of the online education is the function of the virtual techniques, ability to engage and increase the participation of the students, and the ability of effective communication (Easton, 2003; Martin et al., 2019). In addition, Darabi et al. (2006) explained the concept of a functional online course as followed; the course should have specific aims, assignments, evaluations, content, methods of interaction, and structure.

As a conclusion readiness to change for any organization is the crucial factor to adapt its new environment (Ahmad \& Cheng, 2018). In line with this, faculty' or departments' readiness to online education will have positive impacts on their lecturer's perception, classes, student's adaptation, and satisfaction with the new system. Especially, the pandemic process of Covid-19 has accelerated this adaptation due to lockdown in the countries. In this respect, current literature has investigated education institutions' readiness to online education in the following factors: technology, human resource, budget, and infrastructure (Azimi, 2013); computer self-efficacy, internet self-efficacy, online communication, self-directed learning, learner control and motivation towards e-learning (Yilmaz, 2017); technology, innovation, people, and selfdevelopment (Aydın \& Tasci, 2005). According to Tayyib et al. (2020) these dimensions could be more suitable when the organizations are at the beginning phase of the changes. On the other hand, Lokuge et al. (2019) investigated the readiness to change under three main dimensions, which are change valance (support and commitment for change), change efficacy (resources and capabilities for required tasks), and contextual factors (organizational culture). Similarly, Holt and Vardaman (2013) offered mainly three dimensions of individual characters, structural factors, and level analysis (individual and organizational) to evaluate readiness for change based on their literature review. 
Furthermore, Lokuge et al. (2019) defined this adaptation process as modern digitalization, whereas they stated that modern processes for digitalization are more cost advantageous and more suitable to connect various stakeholder groups that minimize the barriers to innovation. Accordingly, the success of the organization by the innovation depends on their flexibility, responsiveness, adaptability to fast changes, fast decision-making capability, and changeable strategies against emulation by competitors. In this respect the models have used the similar criterion to evaluate university readiness to online education. However, the pandemic process is not a free or alternative for the universities. It was an environmental pressure especially for the private education institutions to use online education system. From this point of view, the concept of Lokuge et al. (2019) is more comprehensive and suitable to evaluate institutions readiness to environmental changes and innovation, respectively.

Therefore, current study aims to investigate the readiness of universities as digital innovation under the three main dimensions of change valance (cognitive readiness and innovation valance), change efficacy (resource readiness, IT readiness, and Partnership readiness), and contextual factors (cultural readiness and strategic readiness).

Moreover, Kurdistan is the developing part of Iraq with Erbil, Sulaymaniyah, Duhok, and Halabja cities (Budur, 2018). Depending on the political and economic stability, Kurdistan attracts various international organizations (Budur and Poturak, 2021). Accordingly, Salahuddin University, Sulaymaniyah University, Halabja University, Koya University, Charmo University, and Polytechnic University are the public higher education institutions, while American University in Duhok and Sulaymaniyah, Cihan and Tishk University in Erbil and Sulaymaniyah, Lebanese French University, Komar University, and Human Development University are the private higher education institutions in the region (Budur et al., 2018). Ministry of higher education has decided to apply online education system during the Covid-19 pandemic process like other countries as well. Especially, private universities Tishk International University was one of pioneer institutions that maintain their system from the various software and platforms as online in the region. Based on this pandemic process, current paper will investigate these institutions readiness to online education system in the following sections of the paper.

\section{Background and Hypotheses}

Innovation could be perceived as the organizational activities that aim to adapt its environment with higher productivity. Lokuge et al. (2019) explained innovation as "adaptation, assimilation, exploitation, renewal, enlargement and development" of an organization. To provide an effective innovation in the organization all the company units and members should be ready to follow required changes appropriately whereas this readiness should be applied individual, team, departmental, and organizational level (Helfrich et al., 2011; Molla et al., 2009). As a conclusion based on the readiness theory innovation will be demonstrated as "readiness for change"; as psychological and physiological responses of an organization to adapt complex differences in the market (Weiner, 2020). In line with this, Sanders et al. (2017) defined readiness to change as the effective implementation of individual and organizational resources. Therefore, they suggested to apply changes in two ways of change commitment and change efficacy. 


\subsection{Readiness Theory in Educational Concept}

Based on the three-key metrics of change valance, change efficacy and contextual factors listed before, the present study aims to explore organizational change in seven dimensions of cognitive readiness, innovation valance; resource readiness, IT readiness, partnership readiness; cultural readiness, and strategic readiness influencing Kurdistan universities' preparation for online education based on the Lokuge et al. (2019) conceptualization.

\subsection{Change Valance}

Researchers noted that readiness for change within the company should fulfil the following factors to reach competitive advantage (Weeks, et al., 2004; Weiner et al., 2008). Firstly, the perception about the change for innovation or excelled productivity should be positive within the organization/change valance (Jaros, 2010). Besides, it is argued that "the more staff committed to change the more they will apply requirements" (Ahmad et al., 2020; Weiner, 2009; Mart, 2013a, 2013b). Holt et al. (2007) found that administrative commitment and support have positive impact on the success of the organizational change. Similarly, Yeap et al. (2020) claimed that lecturer's mindfulness and readiness are crucial factors to foster change and increase their commitment for teaching effectiveness. Further, researchers noted based on the social cognition theory external factors have important role in the individual characteristics to changeacceptance (Bandura, 1986; Tran, 2020). In line with this, Yeap et al. (2020) revealed that transformational leaders and their mindfulness for organizational change at university have a significant impact on the lecturer's acceptance and success for the new system.

\subsubsection{Cognitive Readiness}

Cognitive readiness refers to knowledge perception and implication within the company that covers employee's availability and competencies to use required devices and technologies for innovative improvements (Demir et al., 2021; Torlak et al., 2021; Yusof et al., 2010). Further, cognitive readiness involves individual abilities to solve problems that facilitate digitalization (Lokuge et al., 2019). In this respect, cognitive readiness of a company mainly focuses on the ability of the staff to adapt digital innovation rather than being flexible (Altun \& Tahir, 2020; Mart, 2017; Sedera \& Dey, 2013). On the other hand, Shah et al. (2017) put forward that extrinsic factors such as promotion, bonus, and salary have positive effects on employee's attachment to change processes. Besides, according to Weiner (2020), employee motivation to change is positively linked to change efficacy and change commitment, which contributes to cooperative action and effective adoption.

\subsubsection{Innovation Valance}

Innovation valance is employee's motivation about the digitalization. In other meaning, it refers to employee's perception and actions towards changes for innovation within the company (Mueller et al., 2013). Besides, Lokuge et al. (2019) noted that positive attitude and motivation of staff and leader's empowerment have significant impact on the success of the digitalization. Further, Hosseinpour et al. (2019) found that the more participation and flexibility of University lecturers to change, is positively related to their positive perception and acceptance of the change processes. On the other hand, Nilsen et 
al. (2016) and Olafsen et al. (2020) observed that organizations fail to implement changes unless employees do not participate and are not emotionally ready for the transition.

In addition, the attachment of lecturers to e-learning should be accompanied by efficient planning. To date, scholars have recognized that lectures confidence and engagement could be reinforced by asking their views and perceptions about existing university policies and activities (Mohammed et al., 2020).

\subsection{Change Efficacy}

Secondly, change efficacy that refers to capabilities and resources of organization to implement appropriate change policies (Lokuge et al., 2019). Knowledge of staff, strategies to reach objectives, and required time to attain innovation are some of the capabilities, while sufficiency of human, available materials, financial sources, and knowledge utilization are the resources of the company to implement required updates for the innovation (Gärtner, 2013; Poturak et al., 2020). Harun and Mansor (2019) clarified the key distinction between private and public universities, based on capability and resources that public universities concentrate on scientists and research that promotes national development, while private universities focus on ability and expertise to fulfill business' needs. In addition, they observed that appropriateness, management encouragement, change-specific efficacy and personal valence were positively associated with individual ability to adjust their environment at public universities.

On the other hand, Sanders et al. (2017) found that barriers to implement required updates, such as contextual factors, implementation requirements, and perceived value of the program negatively influence the commitment to change. In addition, they have noted during the transition, individuals could focus only on their level rather than organizational success. Lastly, Weimer (2020) claimed that change efficacy strongly affected by organizational members' cognitive appraisals, which are task demands, resource availability, and situational factors.

\subsubsection{Resource Readiness}

An organization's resources are the input variables that are used to create end goods or services. These primary tools are financial and technical aspects, as well as human dimensions (Haney, 2002; Torlak et al., 2019). In this respect, resources of Universities to apply effective digitalization and to adapt online education will be flexible human variables, which means lecturers adaptation to online education, providing different alternative platforms to prepare and present online classes; hence financial support to lecturers might be providing flexible software alternatives and infrastructures to facilitate adaptation to eLearning (Saekow \& Samson, 2011). Furthermore, Jennett et al. (2003) stated that available equipment should be appropriate for the required jobs and should be accessible safely and conveniently so that it can positively affect the organization's performance. Consequently, to avoid employee reluctance to transition, administrative should recommend appropriate communication, assistance, and training programs (Hamid \& Durmaz, 2021; Jennett et al., 2003; Serin, 2020).

\subsubsection{IT Readiness}

IT systems refers to secure and stable information system for employees and customers, suitable internet quality, and UpToDate webpage and social media presentations (Celik \& Yildiz, 2017; Demir et al., 2020) 
that provides enough information about the organization self. Additionally, consistency by these services is another significant factor to improve innovation processes (Kleis et al., 2012). Further, in educational concept, IT readiness is the key factor to train lecturers and students to adapt new system of the University. Providing a strong internet connection, presenting live and offline sessions appropriately, and sharing class materials timely and correctly are some of the important influential factors on the students and lecturer's perception (Mohammed et al., 2020). As the researchers have noted, technological sufficiency and readiness strongly influence the productivity or disadvantage of the processes (Parasuraman \& Colby, 2015; Pham et al., 2020). Besides, Irfan et al. (2018) stated that enough resources in IT systems increase the success of the universities to adapt transition.

\subsubsection{Partnership Readiness}

The external environment of a company, which includes suppliers, clients, and consultants, is referred to as partnership readiness (Haney, 2002). Furthermore, stakeholder preparation is the environment's availability to the organization's creative activities and their transition to the company's new system (Sedera \& Day, 2013). In this respect, organizations want to maintain their existed relationship with their environment in the future. Accordingly, stakeholder readiness in education refers to student's perception and acceptance of new education system. Besides, a strong internet connection that lecturers do not face any problem during the classes is another important factor that universities receive from suppliers. Andrews et al. (2012) investigated partners readiness in the education and put forward that trust and positive relationship are important factors that mediates the relationship between organization and its environment.

\subsection{Contextual Factors}

Lastly, contextual factors that involves the readiness of the organizational culture to implement change policies (Jones, et al., 2005). In this regard, the organization's learning availability, flexibility of norms, and strategies within departments can encourage the necessary adjustments to capture creativity within the organization (Holt et al., 2007).

\subsubsection{Cultural Readiness}

Organizational culture refers to companies' norms, values, and regulations that organize the interactions and relationships for inside and outside of the organization (Jones, 1983). Following this further, cultural readiness corresponds to an organization's cultural capacity to adapt to desired transition (Lee et al., 2016). Furthermore, it is recognized that cultural preparation is one of the critical factors influencing the progress of adaptation to innovation (Lokuge \& Sedera, 2020). Accordingly, Malik and Garg (2017) claimed that in the learning-oriented cultures employees are flexible for change and more committed to innovation. Similarly, Benzer et al. (2017) claimed that communication, coordination, goal alignment, and strategic leadership are important triggers of the individual adaptation for change. In addition, Olafsen et al. (2020) claimed that dynamic organizational culture is more successful by the innovation processes. Further, Benitez et al. (2018) stated that cultural factors of an organization such as knowledge-sharing, decentralized decision-making, and risk sensibility positively related to innovation. 


\subsubsection{Strategic Readiness}

Lokuge et al. (2019) defined strategic readiness as the "set of managerial activities that an organization engages in to facilitate digital innovation". Some of the strategic activities of an organization in terms of suitable communication, clear vision statements, and problem-solving ability are favorably correlated with participants' adaptation to organizational transition (Lee et al., 2016; Mueller et al., 2013). Besides, Benzer et al. (2017) stated that legitimacy, need for change, and resources are important factors that significantly influence the mediation between organizational structure and individual perception for change readiness. Further, Nilsen et al. (2018) argued the importance of the strategies and leadership commitment to promote the adaptation process. They suggested that training significantly improves employees' motivation, skills, and confidence for greater responsiveness.

\section{Methods}

\subsection{Purpose}

The purpose of the current study is to elaborate the readiness of the public and private universities for the online education. The readiness of the universities for the online education was evaluated through sufficiency of resources, culture, strategies, IT infrastructures, innovation valance, cognitive aspects, and partnerships points.

\subsection{Sample}

The study was conducted in Kurdistan Region of Iraq. There are fourteen public and eighteen private universities in the region. In this study, we have sent a questionnaire to the lecturers from those universities. Questionnaire were sent via direct emails to their email addresses. We have sent approximately 2000 emails to the various lecturers in public and private universities in the region. Besides, there have been only 249 survey questionnaires fulfilled appropriately and returned. Due to the COVID 19 , lecturers were working online and were very busy with preparing the online lectures. Hence, response rate was only $12.45 \%$.

We have elaborated the participants from their gender, age, academic title, university that they fill the questionnaire from, type of the university whether public or private, the experience of the lecturer in general, and experience of lecturing at the current university that they fill the questionnaire for. For the further details, please see Table 1. 
Table 1: Demographic elaboration of the sample

\begin{tabular}{|c|c|}
\hline Gender & $\%$ \\
\hline Male & 73.89 \\
\hline Female & 26.1 \\
\hline Age & $\%$ \\
\hline $18-25$ & 8.4 \\
\hline $26-35$ & 35.7 \\
\hline $36-45$ & 34.1 \\
\hline $46-55$ & 14.9 \\
\hline $56+$ & 6.8 \\
\hline Academic title & $\%$ \\
\hline Assistant Lecturer & 43.8 \\
\hline Lecturer & 39.0 \\
\hline Assistant Professor & 12.4 \\
\hline Professor & 4.8 \\
\hline Name of the University & $\%$ \\
\hline Sulaimani University & 0.10 \\
\hline TIU & 0.34 \\
\hline SPU & 0.09 \\
\hline Charmo University & 0.11 \\
\hline Koya University & 0.10 \\
\hline Salahaddin University & 0.14 \\
\hline Other & 0.12 \\
\hline Type of University & $\%$ \\
\hline Public & 61.82 \\
\hline Private & 38.18 \\
\hline General Lecturing Experience & $\%$ \\
\hline $1-3$ years & 22.1 \\
\hline 4-6 years & 27.3 \\
\hline $7-10$ years & 19.7 \\
\hline $11-15$ years & 13.7 \\
\hline $16+$ years & 17.3 \\
\hline Experience at Current University & $\%$ \\
\hline $1-3$ years & 48.2 \\
\hline 4-6 years & 28.5 \\
\hline $7-10$ years & 13.7 \\
\hline $11-15$ years & 6.4 \\
\hline $16+$ years & 3.2 \\
\hline
\end{tabular}




\subsection{Instrumentation}

There were 8 dimensions by which we have evaluated the readiness of the universities for online education. Those dimensions were mainly resource readiness (three items), cultural readiness (three items), strategic readiness (three items), IT readiness (three items), innovation valance (three items), cognitive readiness (three items), partnership readiness (three items), and readiness in general (three items).

The questions were adopted from the study of Lokuge et al. (2019). They have studied the model in the readiness for organizational innovation. Moreover, we have adopted their dimensions, and modified their questions to be used in the readiness for online education field. We have used 1 to 9 rating-index, where 1 represented insufficiency whilst 9 represented perfect readiness.

\section{Results}

\subsection{Validity and Reliability}

Initial reliability analysis was conducted via Cronbach's alpha method. It is known that minimum value of the Cronbach's alpha must hold 0.7 so that a construct can be considered as reliable enough (Demir, 2020a). Given in the Table 3, it was observed that reliability levels of the constructs change between 0.88 and 0.97 . Hence, initial checks resulted with high reliability. 
Table 2: Confirmatory factor analysis results of factor loads

\begin{tabular}{|c|c|c|c|c|c|c|c|}
\hline \multicolumn{7}{|c|}{ Rotated Component Matrix ${ }^{\mathrm{a}}$} \\
\hline Items & \multicolumn{7}{|c|}{ Components } \\
\cline { 2 - 9 } & $\begin{array}{c}\text { Innovation } \\
\text { Valance }\end{array}$ & $\begin{array}{c}\text { Resource } \\
\text { Readiness }\end{array}$ & $\begin{array}{c}\text { Partnership } \\
\text { Readiness }\end{array}$ & $\begin{array}{c}\text { Culture } \\
\text { Readiness }\end{array}$ & $\begin{array}{c}\text { Strategic } \\
\text { Readiness }\end{array}$ & $\begin{array}{c}\text { IT } \\
\text { Readiness }\end{array}$ & $\begin{array}{c}\text { Cognitive } \\
\text { Readiness }\end{array}$ \\
\hline RR1 & 0.34 & $\underline{0.790}$ & 0.268 & 0.148 & 0.241 & 0.17 & 0.112 \\
\hline RR2 & 0.412 & $\underline{0.731}$ & 0.211 & 0.295 & 0.158 & 0.165 & 0.18 \\
\hline RR3 & 0.309 & $\underline{0.595}$ & 0.345 & 0.313 & 0.207 & 0.216 & 0.295 \\
\hline CR1 & 0.354 & 0.371 & 0.295 & $\underline{0.658}$ & 0.226 & 0.288 & 0.111 \\
\hline CR2 & 0.386 & 0.271 & 0.299 & $\underline{0.614}$ & 0.268 & 0.116 & 0.343 \\
\hline CR3 & 0.358 & 0.313 & 0.346 & $\underline{0.479}$ & 0.379 & 0.276 & 0.138 \\
\hline SR1 & 0.253 & 0.287 & 0.277 & 0.264 & $\underline{0.591}$ & 0.212 & 0.311 \\
\hline SR2 & 0.332 & 0.418 & 0.264 & 0.286 & $\underline{0.557}$ & 0.248 & 0.173 \\
\hline SR3 & 0.221 & 0.266 & 0.154 & 0.331 & $\underline{0.521}$ & 0.352 & 0.343 \\
\hline ITR1 & 0.343 & 0.423 & 0.328 & 0.259 & 0.304 & $\underline{0.528}$ & 0.407 \\
\hline ITR2 & 0.297 & 0.198 & 0.216 & 0.171 & 0.168 & $\underline{0.853}$ & 0.148 \\
\hline ITR3 & 0.477 & 0.349 & 0.313 & 0.243 & 0.184 & $\underline{0.513}$ & 0.384 \\
\hline IV1 & $\underline{0.763}$ & 0.267 & 0.247 & 0.274 & 0.187 & 0.201 & 0.132 \\
\hline IV2 & $\underline{0.672}$ & 0.341 & 0.147 & 0.356 & 0.141 & 0.213 & 0.267 \\
\hline IV3 & $\underline{0.690}$ & 0.261 & 0.241 & 0.335 & 0.178 & 0.191 & 0.323 \\
\hline CGR1 & 0.244 & 0.244 & 0.196 & 0.187 & 0.242 & 0.257 & $\underline{0.762}$ \\
\hline CGR2 & 0.311 & 0.349 & 0.159 & 0.227 & 0.145 & 0.088 & $\underline{0.775}$ \\
\hline CGR3 & 0.333 & 0.237 & 0.143 & 0.334 & 0.233 & 0.065 & $\underline{0.750}$ \\
\hline PR1 & 0.265 & 0.203 & $\underline{0.597}$ & 0.288 & 0.124 & 0.266 & 0.389 \\
\hline PR2 & 0.31 & 0.258 & $\underline{0.552}$ & 0.249 & 0.077 & 0.301 & 0.366 \\
\hline PR3 & 0.363 & 0.262 & $\underline{0.546}$ & 0.304 & 0.114 & 0.231 & 0.343 \\
\hline Extraction Method: Principal Component Analysis. & & & \\
a. Rotation converged in 8 iterations. & & & & & \\
Rotation Method: Varimax with Kaiser Normalization. & & & & & \\
\hline & & & & & & & \\
\hline
\end{tabular}

Secondly, we have conducted exploratory factor analysis to evaluate the priori validity of the questionnaire. We have started evaluating the results from the Kaiser-Meyer-Olkin measure of sampling test results (KMO). In this section, KMO level is expected to be above 0.5 (Demir 2020b). Based on our observation, KMO level was 0.97 and Bartlett's test of sphericity was significant at $\mathrm{P}<0.01$. Therefore, it can be concluded that the collected data is sufficient to go further with the analysis. 
Table 3: Confirmatory factor analysis results of communalities and explained variance

\begin{tabular}{|c|c|c|c|c|c|}
\hline Items & Mean & $\begin{array}{c}\text { Std. } \\
\text { Deviation }\end{array}$ & Extraction & $\begin{array}{c}\text { Cronbach's } \\
\text { Alpha }\end{array}$ & Explained Variance \\
\hline RR1 & 5.92 & 2.404 & 0.933 & \multirow[t]{3}{*}{0.942} & \multirow[t]{3}{*}{$27.0 \%$} \\
\hline RR2 & 6.04 & 2.316 & 0.920 & & \\
\hline RR3 & 6.09 & 2.288 & 0.917 & & \\
\hline CR1 & 6.24 & 2.286 & 0.930 & \multirow[t]{3}{*}{0.920} & \multirow[t]{3}{*}{$16.6 \%$} \\
\hline CR2 & 5.80 & 2.362 & 0.892 & & \\
\hline CR3 & 6.02 & 2.205 & 0.869 & & \\
\hline SR1 & 5.92 & 2.360 & 0.925 & \multirow[t]{3}{*}{0.926} & \multirow[t]{3}{*}{$12.5 \%$} \\
\hline SR2 & 6.02 & 2.345 & 0.914 & & \\
\hline SR3 & 5.99 & 2.343 & 0.889 & & \\
\hline ITR1 & 5.95 & 2.407 & 0.931 & \multirow[t]{3}{*}{0.882} & \multirow[t]{3}{*}{$11.0 \%$} \\
\hline ITR2 & 6.71 & 2.169 & 0.980 & & \\
\hline ITR3 & 6.01 & 2.278 & 0.903 & & \\
\hline IV1 & 5.80 & 2.194 & 0.881 & \multirow[t]{3}{*}{0.940} & \multirow[t]{3}{*}{$8.8 \%$} \\
\hline IV2 & 5.88 & 2.318 & 0.853 & & \\
\hline IV3 & 5.96 & 2.286 & 0.885 & & \\
\hline CGR1 & 5.78 & 2.319 & 0.897 & \multirow[t]{3}{*}{0.958} & \multirow[t]{3}{*}{$8.6 \%$} \\
\hline CGR2 & 5.98 & 2.249 & 0.924 & & \\
\hline CGR3 & 5.99 & 2.258 & 0.919 & & \\
\hline PR1 & 6.03 & 2.251 & 0.935 & \multirow[t]{3}{*}{0.966} & \multirow[t]{3}{*}{$6.4 \%$} \\
\hline PR2 & 6.09 & 2.308 & 0.920 & & \\
\hline PR3 & 6.04 & 2.227 & 0.908 & & \\
\hline
\end{tabular}

Secondly, Table 2 shows the results of the factor loads. Given in the table, it was observed that all items were loaded under their planned dimension more than did under any other dimensions. Hence, designed questions were appropriately distributed among the dimensions they have been planned for. However, Table 3 shows the communalities and explained variance of the questionnaire. Based on the results, it was revealed that all items hold values above 0.5 not to be extracted (Demir, et al., 2020c). Lastly, the survey questionnaire has explained variance above 0.5 in total so that is valid.

After all, we have conducted the construct validity via evaluating the average variance explained (AVE). In this point, all the dimensions are expected to hold value above 0.5 . Secondly, composite reliability of each variable is expected to be above 0.7 . Therefore, convergent validity would be achieved. Lastly, square root of average variance explained must be above the correlation of that variable with other dimensions. So that the discriminant validity would be achieved. Given in the Table 4 are the results of convergent validity. Based on the results, it was observed that average variance extracted for each dimension was above 0.5 and composite reliability for each dimension was more than 0.7 . Hence, convergent validity was achieved. 
Table 4: Convergent validity

\begin{tabular}{|c|c|c|c|c|c|c|c|}
\hline Item & SL & SSL & SSSL & NOI & AVE & $\begin{array}{l}\text { SQRT of } \\
\text { AVE }\end{array}$ & C.R. \\
\hline \multicolumn{8}{|c|}{ Resource Readiness } \\
\hline RR3 & 0.945 & 0.893 & \multirow[t]{3}{*}{2.694} & \multirow[t]{3}{*}{3} & \multirow[t]{3}{*}{0.898} & \multirow[t]{3}{*}{0.948} & \multirow[t]{3}{*}{0.964} \\
\hline RR2 & 0.953 & 0.908 & & & & & \\
\hline RR1 & 0.945 & 0.893 & & & & & \\
\hline \multicolumn{8}{|c|}{ Cultural Readiness } \\
\hline CR3 & 0.925 & 0.856 & \multirow[t]{3}{*}{2.597} & \multirow[t]{3}{*}{3} & \multirow[t]{3}{*}{0.866} & \multirow[t]{3}{*}{0.930} & \multirow[t]{3}{*}{0.951} \\
\hline CR2 & 0.929 & 0.863 & & & & & \\
\hline CR1 & 0.937 & 0.878 & & & & & \\
\hline \multicolumn{8}{|c|}{ Strategic Readiness } \\
\hline SR3 & 0.917 & 0.841 & \multirow[t]{3}{*}{2.621} & \multirow[t]{3}{*}{3} & \multirow[t]{3}{*}{0.874} & \multirow[t]{3}{*}{0.935} & \multirow[t]{3}{*}{0.954} \\
\hline SR2 & 0.939 & 0.882 & & & & & \\
\hline SR1 & 0.948 & 0.899 & & & & & \\
\hline \multicolumn{8}{|c|}{ IT Readiness } \\
\hline ITR3 & 0.933 & 0.870 & \multirow[t]{3}{*}{2.421} & \multirow[t]{3}{*}{3} & \multirow[t]{3}{*}{0.807} & \multirow[t]{3}{*}{0.898} & \multirow[t]{3}{*}{0.926} \\
\hline ITR2 & 0.830 & 0.689 & & & & & \\
\hline ITR1 & 0.928 & 0.861 & & & & & \\
\hline \multicolumn{8}{|c|}{ Innovation Valance } \\
\hline IV3 & 0.953 & 0.908 & \multirow[t]{3}{*}{2.675} & \multirow[t]{3}{*}{3} & \multirow[t]{3}{*}{0.892} & \multirow[t]{3}{*}{0.944} & \multirow[t]{3}{*}{0.961} \\
\hline IV2 & 0.946 & 0.895 & & & & & \\
\hline IV1 & 0.934 & 0.872 & & & & & \\
\hline \multicolumn{8}{|c|}{ Cognitive Readiness } \\
\hline CGR3 & 0.962 & 0.925 & 2.773 & 3 & 0.924 & 0.961 & 0.973 \\
\hline CGR2 & 0.967 & 0.935 & & & & & \\
\hline CGR1 & 0.955 & 0.912 & & & & & \\
\hline Partner & & & & & & & \\
\hline PR3 & 0.941 & 0.885 & 2.717 & 3 & 0.906 & 0.952 & 0.966 \\
\hline PR2 & 0.953 & 0.908 & & & & & \\
\hline PR1 & 0.961 & 0.924 & & & & & \\
\hline
\end{tabular}

*** SL: standardized loadings; SSL: squares of standardized loadings; SSSL: sum of squares of standardized loadings; NOI: number of items; AVE: average variance extracted; SQRT of AVE: square root of average variance extracted.

After convergent validity, we have constructed the discriminant validity table. Based on the results given in the Table 5, it was seen that each squared root of average variance extracted was above the values of correlation for one dimension to other dimensions. Thus, discriminant validity was also achieved. 
Table 5: Discriminant validity

\begin{tabular}{|l|l|l|l|l|l|l|l|}
\hline & 1 & 2 & 3 & 4 & 5 & 6 & 7 \\
\hline Resource Readiness & 0.948 & & & & & & \\
\hline Cultural Readiness & 0.866 & 0.930 & & & & & \\
\hline Strategic Readiness & 0.841 & 0.898 & 0.935 & & & & \\
\hline IT Readiness & 0.847 & 0.884 & 0.890 & 0.898 & & & \\
\hline Innovation Valance & 0.803 & 0.845 & 0.864 & 0.845 & 0.944 & & \\
\hline Cognitive Readiness & 0.791 & 0.811 & 0.846 & 0.832 & 0.909 & 0.961 & \\
\hline Partnership Readiness & 0.874 & 0.898 & 0.880 & 0.918 & 0.869 & 0.870 & 0.952 \\
\hline
\end{tabular}

***** Bold italic numbers: square root of average variance extracted; not bold and not italic numbers: correlation values.

\subsection{Hypotheses Testing}

After the validation of the questionnaire, we have tested the hypotheses results via independent samples $t$ test. In this regard, we aimed to elaborate the differences between public and private universities in the Region.

Table 6: Independent samples t test

\begin{tabular}{|c|c|c|c|c|c|c|c|}
\hline Dimensions & $\begin{array}{l}\text { University } \\
\text { Type }\end{array}$ & $\mathrm{N}$ & Mean & $\begin{array}{l}\text { Std. } \\
\text { Deviation }\end{array}$ & T stat & P Value & Result \\
\hline \multirow[t]{2}{*}{ Resource Readiness } & Public & 95 & 4.856 & 2.086 & \multirow[t]{2}{*}{-5.589} & \multirow[t]{2}{*}{0.000} & \multirow[t]{2}{*}{ Significant } \\
\hline & Private & 154 & 6.488 & 2.089 & & & \\
\hline \multirow[t]{2}{*}{ Cultural Readiness } & Public & 95 & 4.653 & 1.926 & \multirow[t]{2}{*}{-7.105} & \multirow[t]{2}{*}{0.000} & \multirow[t]{2}{*}{ Significant } \\
\hline & Private & 154 & 6.576 & 1.941 & & & \\
\hline \multirow[t]{2}{*}{ Strategic Readiness } & Public & 95 & 4.782 & 1.953 & \multirow[t]{2}{*}{-5.830} & \multirow[t]{2}{*}{0.000} & \multirow[t]{2}{*}{ Significant } \\
\hline & Private & 154 & 6.461 & 2.102 & & & \\
\hline \multirow[t]{2}{*}{ IT Readiness } & Public & 95 & 4.991 & 1.854 & \multirow[t]{2}{*}{-6.518} & \multirow[t]{2}{*}{0.000} & \multirow[t]{2}{*}{ Significant } \\
\hline & Private & 154 & 6.725 & 1.923 & & & \\
\hline \multirow[t]{2}{*}{ Innovation Valance } & Public & 95 & 4.745 & 1.849 & \multirow[t]{2}{*}{-5.644} & \multirow[t]{2}{*}{0.000} & \multirow[t]{2}{*}{ Significan } \\
\hline & Private & 154 & 6.339 & 2.085 & & & \\
\hline \multirow[t]{2}{*}{ Cognitive Readiness } & Public & 95 & 4.931 & 1.876 & \multirow[t]{2}{*}{-4.721} & \multirow[t]{2}{*}{0.000} & \multirow[t]{2}{*}{ Significant } \\
\hline & Private & 154 & 6.315 & 2.180 & & & \\
\hline \multirow{2}{*}{$\begin{array}{l}\text { Partnership } \\
\text { Readiness }\end{array}$} & Public & 95 & 4.699 & 1.966 & \multirow[t]{2}{*}{-6.774} & \multirow[t]{2}{*}{0.000} & \multirow[t]{2}{*}{ Significant } \\
\hline & Private & 154 & 6.606 & 2.034 & & & \\
\hline \multirow{2}{*}{$\begin{array}{l}\text { Readiness in } \\
\text { General }\end{array}$} & Public & 95 & 4.606 & 2.057 & \multirow[t]{2}{*}{-5.664} & \multirow[t]{2}{*}{0.000} & \multirow[t]{2}{*}{ Significant } \\
\hline & Private & 154 & 6.277 & 2.131 & & & \\
\hline
\end{tabular}

Given in the Table 6, there are mean values for dimensions of readiness of public and private universities for online education in Kurdistan Region of Iraq. Based on the results, it was observed that there are gaps in readiness for online education between public and private universities. When the Table 6 is investigated, 
one the difference or gap between those universities is resource readiness. The evaluations of the lecturers at those universities indicate that private universities allocate much more financial, human, and IT resources for online education comparing to the public universities. However, lecturers rated the resource allocation of public universities around the average while public university lecturers rated higher than average.

Second gap between public and private universities in the region was cultural readiness. It was seen on the table that private universities created better decision making, idea sharing, and risk engagement environment to become ready for the online education comparing to the public universities. Cultural readiness required university administration to establish way of idea and experience sharing to engage with the online education, decentralize the decision making for conveniently establish online education management, and analyze the risks to reduce IT problems during the online education. However, from those aspects public university lecturers rated their university close to poor whilst the private university lecturers rated above the average.

Third gap between the public and private universities was strategic readiness. In this regard, we evaluated how clear, understandable, and communicable the university strategic goals were for the lecturers who would execute online education in charge with students. Based on the evaluation results, it was observed that private universities significantly were better in strategic readiness comparing to the public universities in the Region.

Fourth, one of the most important aspect for online education, information technology infrastructure was evaluated between public and private universities. Given in the results, it was revealed that it system in the private universities were more stable, up to date, and reliable, lecturers in private universities were more adoptable and had range to access the online education platforms (zoom, google meet...etc.), and IT infrastructure in the private universities were significantly more stable than public universities in the region.

Innovation valance represented how knowledgeable, motivated, and empowered the lecturers were in the universities. Secondly, whether the lecturers had technical and organizational knowledge to manage online education sessions, skills to apply online education, adaptability to apply online education. Given in the evaluation results of the lecturers, it was observed that private universities were significantly better in innovation valance and cognitive readiness points comparing to the public universities.

During the period of online education, one of the biggest struggles was to find the appropriate and convenient software for online education. Most of the universities used Zoom during this time (Demir et al., 2020a). On the other hand, online education required more complex and reliable software to evaluate student performances, attendances, and deliver a quality education. In this regard, we have evaluated the partnership readiness of the universities. In this section, lecturers evaluated how good relations did the university had with the software vendors, management consultants, and IT suppliers to apply online education appropriately. It was observed that private universities were significantly better performing in partnership relations comparing to public universities. 
In general, it was observed that private universities are more ready for the online education and adopted better comparing to the public universities, in all points of the online education readiness that we have evaluated, it was observed that public universities were not ready for the contemporary online education yet. It was seen from the analyses that public universities could not survive above average in all dimensions. Especially cultural readiness, which means sharing the ideas in a decentralized way to find the best way of online education and taking reasonable risks for engaging IT to facilitate online education, was the weakest points of public universities.

\section{Conclusions}

The aim of this research was to explore the readiness of the universities for online education in Kurdistan Region of Iraq. The new age and COVID 19 shown that the online education will be irrevocable way of education in the world. Therefore, public and private education institutions supposed to do a SWOT analysis for their readiness and compensate their weaknesses soon. In this regard, we have developed a questionnaire to assess the readiness of those universities in the region from resource readiness, strategic readiness, cultural readiness, IT readiness, cognitive readiness, partnership readiness and innovation valance points of views.

The results have revealed that both in private and public universities the readiness is not very high yet. It might be because the sudden entry into the online education, especially, cultural readiness, cognitive readiness, strategic readiness, and innovation valance dimensions need further improvements as soon as possible.

Additionally, it was observed that in comparison with the private universities, the problems of public universities in the region seems to be more severe. A crucial gap was observed in all dimensions of the current research between public and private universities.

In these regards, we suggest universities in Kurdistan Region of Iraq to

- Get ready from the resources point of view via:

○ Planning and allocating adequate financial resources necessary to apply online education,

- Planning allocating adequate human resources necessary to apply online education,

- Planning allocating adequate IT infrastructure resources necessary to apply online education.

- Secondly, the universities are suggested to get ready culturally for the online education via.

○ Decentralizing the decision-making fields for improvement of online education system,

- Letting all lecturers to participate and share their ideas in the improvement meetings of the online education,

○ Taking reasonable risks after those meetings to facilitate IT for the online education.

- Thirdly, the universities need to improve their strategic plan to get ready for the online education via.

- Making clear and relevant strategic goals specifically for every organizational member, who are related to the online education somehow, when engaging the IT to facilitate online education, 
- Communicating those strategic goals to each member to motivate them to achieve those goals.

- Forth, the universities in Kurdistan Region of Iraq are suggested to get ready for the online education from the IT points of view via.

- Developing a stable, up-to-date, and reliable IT system and infrastructure to facilitate online education,

○ Developing special platforms or contracting with those platform providers for organizational members to access to a range of new technologies like zoom, google hangouts, google meet...etc. available to facilitate online education,

- Fifth, to get ready for the online education, the universities are supposed to improve the innovation valance and knowledge of their staff via.

$\circ$ Providing special training programs to get used to specifications of online education from the pedagogy, technical, and technological points of view.

- Lastly, they need to get ready for the online education via.

- Developing good relationships with the software vendors, management consultants, and IT suppliers and vendors to facilitate online education,

In conclusion, we have developed a robust questionnaire which is able to measure the readiness of the universities for the online education. The questionnaire can be applied in every culture comfortably.

\section{References}

Ahmad, A. B., \& Cheng, Z. (2018). The role of change content, context, process, and leadership in understanding employees' commitment to change: The case of public organizations in Kurdistan region of Iraq. Public Personnel Management, 47(2), 195-216.

Ahmad, A. B., Straatmann, T., Mueller, K., \& Liu, B. (2020). Employees' Change Support in the Public Sector-A Multi-Time Field Study Examining the Formation of Intentions and Behaviors. Public Administration Review.

Andrews, J. O., Newman, S. D., Meadows, O., Cox, M. J., \& Bunting, S. (2012). Partnership readiness for community-based participatory research. Health Education Research, 27(4), 555-571.

Altun, M., \& Tahir, R. (2020). Motivational Techniques in EFL Classrooms in the Universities of Kurdistan. International Journal of Social Sciences \& Educational Studies, 7(1), 88-94.

Aydın, C. H., \& Tasci, D. (2005). Measuring readiness for e-learning: Reflections from an emerging country. Journal of Educational Technology \& Society, 8(4), 244-257.

Azimi, H. M. (2013). Readiness for implementation of e-learning in colleges of education. Journal of Novel Applied Sciences, 2(12), 769-775.

Bandura, A. (1986). Social foundations of thought and action. Englewood Cliffs, NJ, 1986, 23-28.

Benzer, J. K., Charns, M. P., Hamdan, S., \& Afable, M. (2017). The role of organizational structure in readiness for change: A conceptual integration. Health services management research, 30(1), 34-46.

Buckenmeyer, J., Hixon, E., Barczyk, C. C., \& Feldman, L. (2011). Invest in the Success of Online Programs at the University? Mentor Professors. Contemporary Issues in Education Research, 4(6), 1-6.

Budur, T. (2018). Analytic hierarchy process to evaluate corporate image, trust, and switching cost of GSM operators: A case of Kurdistan Region of Iraq. International Journal of Social Sciences \& Educational Studies, 5(2), 241-250. 
Budur, T., \& Poturak, M. (2021). Transformational leadership and its impact on customer satisfaction. Measuring mediating effects of organisational citizenship behaviours. Middle East Journal of Management, 8(1), 67-91.

Budur, T., Rashid, C. A., \& Poturak, M. (2018). Students' perceptions on university selection, decision making process: A case study in Kurdistan Region of Iraq. International Journal of Social Sciences \& Educational Studies, 5(1), 133-144.

Celik, B., \& Yildiz, Y. (2017). Commitment to the teaching profession. International Journal of Social Sciences \& Educational Studies, 4(2), 93-97.

Chen, Y., Wang, Y., Nevo, S., Benitez, J., \& Kou, G. (2017). Improving strategic flexibility with information technologies: insights for firm performance in an emerging economy. Journal of Information Technology, 32(1), 10-25.

Cheon, J., Lee, S., Crooks, S. M., \& Song, J. (2012). An investigation of mobile learning readiness in higher education based on the theory of planned behavior. Computers \& Education, 59(3), 1054-1064.

Cutri, R. M., \& Mena, J. (2020). A critical reconceptualization of faculty readiness for online teaching. Distance Education, 41(3), 361-380.

Darabi, A. A., Sikorski, E. G., \& Harvey, R. B. (2006). Validated competencies for distance teaching. Distance Education, 27(1), 105-122.

Demir, A., Budur, T., Hiwa, M., \& Heshmati, A. (2021). Links between Knowledge Management and Organizational Sustainability: Does the ISO 9001 certification have an effect? Knowledge Management Research \& Practice (TKMR), Doi: 10.1080/14778238.2020.1860663

Demir, A. (2020b). Impact of Internal Marketing on the Customer Perceptions in SMEs. International Journal of Services and Operations Management. DOI: 10.1504/IJSOM.2020.10033103

Demir, A., Budur, T., \& Heshmati, A. (2020 c). Antecedents of trust, corporate image, and switching costs: a case in telecommunication services in the Kurdistan region of Iraq. International Journal of Mobile Communications, 19(1), 53-74.

Demir, A., Maroof, L., Khan, N. U. S., \& Ali, B. J. (2020 a). The role of E-service quality in shaping online meeting platforms: a case study from higher education sector. Journal of Applied Research in Higher Education.

Easton, S. S. (2003). Clarifying the instructor's role in online distance learning. Communication Education, 52(2), 87-105.

Gärtner, C. (2013). Enhancing readiness for change by enhancing mindfulness. Journal of Change Management, 13(1), 52-68.

Hamid, D., \& Durmaz, O. (2021). Organizational culture impact on employee innovative behaviors in Kurdistan. Black Sea Journal of Management and Marketing, 2(1), 63-72.

Haney, D. (2002). Assessing organizational readiness for e-learning: 70 questions to ask. Performance Improvement, 41(4), 8-13.

Harun, A., \& Mansor, Z. (2019). Individual readiness for change in the pre-implementation phase of campus Enterprise Resource Planning (ERP) project in Malaysian Public University. Int. J. Adv. Comput. Sci. Appl, 10, 128-134.

Helfrich, C. D., Blevins, D., Smith, J. L., Kelly, P. A., Hogan, T. P., Hagedorn, H., ... \& Sales, A. E. (2011). Predicting implementation from organizational readiness for change: a study protocol. Implementation Science, 6(1), 76.

Holt, D. T., \& Vardaman, J. M. (2013). Toward a comprehensive understanding of readiness for change: The case for an expanded conceptualization. Journal of Change Management, 13(1), 9-18.

Holt, D. T., Armenakis, A. A., Feild, H. S., \& Harris, S. G. (2007). Readiness for organizational change: The systematic development of a scale. The Journal of Applied Behavioral Science, 43(2), 232-255. 
Holt, D. T., Armenakis, A. A., Harris, S. G., \& Feild, H. S. (2007). Toward a comprehensive definition of readiness for change: A review of research and instrumentation. Research in Organizational Change and Development, 16(1), 289-336.

Hosseinpour, M., Koraei, A., \& Nasiri, M. (2019). Prediction of the readiness to change acceptance of university staff based on organizational culture components. Journal of Career \& Organizational Counseling, 10(37), 71-90

Irfan, M., Putra, S. J., Alam, C. N., Subiyakto, A., \& Wahana, A. (2018). Readiness factors for information system strategic planning among universities in developing countries: Systematic Higher Education, 9, 12.

Jaros, S. (2010). Commitment to organizational change: A critical review. Journal of Change Management, 10(1), 79-108.

Jennett, P., Yeo, M., Pauls, M., \& Graham, J. (2003). Organizational readiness for telemedicine: implications for success and failure. Journal of Telemedicine and Telecare, 9(2_suppl), 27-30.

Jones, G. R. (1983). Transaction costs, property rights, and organizational culture: An exchange perspective. Administrative Science Quarterly, 454-467.

Jones, R. A., Jimmieson, N. L., \& Griffiths, A. (2005). The impact of organizational culture and reshaping capabilities on change implementation success: The mediating role of readiness for change. Journal of Management Studies, 42(2), 361-386.

Kleis, L., Chwelos, P., Ramirez, R. V., \& Cockburn, I. (2012). Information technology and intangible output: The impact of IT investment on innovation productivity. Information Systems Research, 23(1), 42-59.

Lee, M. T., Raschke, R. L., \& Louis, R. S. (2016). Exploiting organizational culture: Configurations for value through knowledge worker's motivation. Journal of Business Research, 69(11), 54425447.

Lloyd, S. A., Byrne, M. M., \& McCoy, T. S. (2012). Faculty-perceived barriers of online education. Journal of Online Learning and Teaching, 8(1).

Lokuge, S., \& Sedera, D. (2020). Enterprise systems lifecycle-wide innovation readiness. arXiv preprint arXiv:2006.05089.

Lokuge, S., Sedera, D., Grover, V., \& Dongming, X. (2019). Organizational readiness for digital innovation: Development and empirical calibration of a construct. Information \& Management, 56(3), 445-461.

Malik, P., \& Garg, P. (2017). The relationship between learning culture, inquiry and dialogue, knowledge sharing structure and affective commitment to change. Journal of Organizational Change Management.

Mart, Ç.T. (2013a). A passionate teacher: Teacher commitment and dedication to student learning. International Journal of Academic Research in Progressive Education and Development, 2(1), 437-442.

Mart, Ç.T. (2013b). Commitment to school and students. International Journal of Academic Research in Business and Social Sciences, 3(1), 336-340.

Mart, Ç.T. (2017). Student evaluations of teaching effectiveness in higher education. International Journal of Academic Research in Business and Social Sciences, 7(10), 57-61.

Martin, F., Budhrani, K., \& Wang, C. (2019). Examining faculty perception of their readiness to teach online. Online Learning, 23(3), 97-119.

Mohammed, K. S., Rashid, C. A., Salih, H. A., \& Budur, T. (2020). The role of online teaching tools on the perception of the students during the lockdown of Covid-19. International Journal of Social Sciences \& Educational Studies, 7(3), 178-190.

Molla, A., Cooper, V. A., \& Pittayachawan, S. (2009). IT and eco-sustainability: Developing and validating a green IT readiness model. ICIS 2009 proceedings, 141. 
Mueller, V., Rosenbusch, N., \& Bausch, A. (2013). Success patterns of exploratory and exploitative innovation: A meta-analysis of the influence of institutional factors. Journal of Management, 39(6), 1606-1636.

Nilsen, E. R., Dugstad, J., Eide, H., Gullslett, M. K., \& Eide, T. (2016). Exploring resistance to implementation of welfare technology in municipal healthcare services-a longitudinal case study. BMC Health Services Research, 16(1), 657.

Nilsen, P., Wallerstedt, B., Behm, L., \& Ahlström, G. (2018). Towards evidence-based palliative care in nursing homes in Sweden: a qualitative study informed by the organizational readiness to change theory. Implementation Science, 13(1), 1.

Olafsen, A. H., Nilsen, E. R., Smedsrud, S., \& Kamaric, D. (2020). Sustainable development through commitment to organizational change: The implications of organizational culture and individual readiness for change. Journal of Workplace Learning.

Parasuraman, A., \& Colby, C. L. (2015). An updated and streamlined technology readiness index: TRI 2.0. Journal of Service Research, 18(1), 59-74.

Pham, L., Williamson, S., Lane, P., Limbu, Y., Nguyen, P. T. H., \& Coomer, T. (2020). Technology readiness and purchase intention: Role of perceived value and online satisfaction in the context of luxury hotels. International Journal of Management and Decision Making, 19(1), 91-117.

Poturak, M., Mekić, E., Hadžiahmetović, N., \& Budur, T. (2020). Effectiveness of transformational leadership among different cultures. International Journal of Social Sciences \& Educational Studies, 7(3), 119-129.

Rafferty, A. E., Jimmieson, N. L., \& Armenakis, A. A. (2013). Change readiness: A multilevel review. Journal of Management, 39(1), 110-135.

Saekow, A., \& Samson, D. (2011). E-learning Readiness of Thailand's Universities comparing to the USA's Cases. International Journal of e-Education, e-Business, e-Management and eLearning, 1(2), 126.

Sanders, K. A., Wolcott, M. D., McLaughlin, J. E., D'Ostroph, A., Shea, C. M., \& Pinelli, N. R. (2017). Organizational readiness for change: Preceptor perceptions regarding early immersion of student pharmacists in health-system practice. Research in Social and Administrative Pharmacy, 13(5), 1028-1035.

Sedera, D., \& Dey, S. (2013). User expertise in contemporary information systems: Conceptualization, measurement, and application. Information \& Management, 50(8), 621-637.

Serin, H. (2020). The impact of technology-aided instruction on motivation of geometry learners. International Journal of Social Sciences \& Educational Studies, 7(3), 63-72.

Shah, N., Irani, Z., \& Sharif, A. M. (2017). Big data in an HR context: Exploring organizational change readiness, employee attitudes and behaviors. Journal of Business Research, 70, 366-378.

Tayyib, N. A., Ramaiah, P., Alshmemri, M. S., Alsolami, F. J., Lind-say, G. M., Alsulami, S. A., \& Asfour, H. I. (2020). Faculty members' readiness implementing e-learning in higher education Saudi Universities: A cross-sectional study. Indian Journal of Science and Technology, 13(25), 2558-2564.

Torlak, N. G., Demir, A., \& Budur, T. (2019). Impact of operations management strategies on customer satisfaction and behavioral intentions at café-restaurants. International Journal of Productivity and Performance Management, 69(9), 1903-1924.

Torlak, N. G., Demir, A., \& Budur, T. (2021). Decision-making, leadership, and performance links in private education institutes. Rajagiri Management Journal. Doi:10.1108/RAMJ-10-20200061.

Tran, N. (2020). Factors affecting knowledge sharing behavior of lecturers: The case of public universities. Management Science Letters, 10(12), 2789-2798. 
Weeks, W. A., Roberts, J., Chonko, L. B., \& Jones, E. (2004). Organizational readiness for change, individual fear of change, and sales manager performance: An empirical investigation. Journal of Personal Selling \& Sales Management, 24(1), 7-17.

Weiner, B. J. (2009). A theory of organizational readiness for change. Implementation Science, 4, 67.

Weiner, B. J. (2020). A theory of organizational readiness for change. In Handbook on Implementation Science. Edward Elgar Publishing.

Weiner, B. J., Amick, H., \& Lee, S. Y. D. (2008). Conceptualization and measurement of organizational readiness for change: a review of the literature in health services research and other fields. Medical Care Research and Review, 65(4), 379-436.

Yeap, S. B., Abdullah, A. G. K., \& Thien, L. M. (2020). Lecturers' commitment to teaching entrepreneurship: do transformational leadership, mindfulness, and readiness for change matter? Journal of Applied Research in Higher Education.

Yilmaz, R. (2017). Exploring the role of e-learning readiness on student satisfaction and motivation in flipped classroom. Computers in Human Behavior, 70, 251-260.

Yusof, N. A. B., Shafiei, M. W. M., Said, I., \& Abidin, N. Z. (2010). Factors influencing firms' readiness towards innovation in house building industry: A multi-dimensional construct. International Journal of Organizational Innovation, 2(3). 


\section{Appendix}

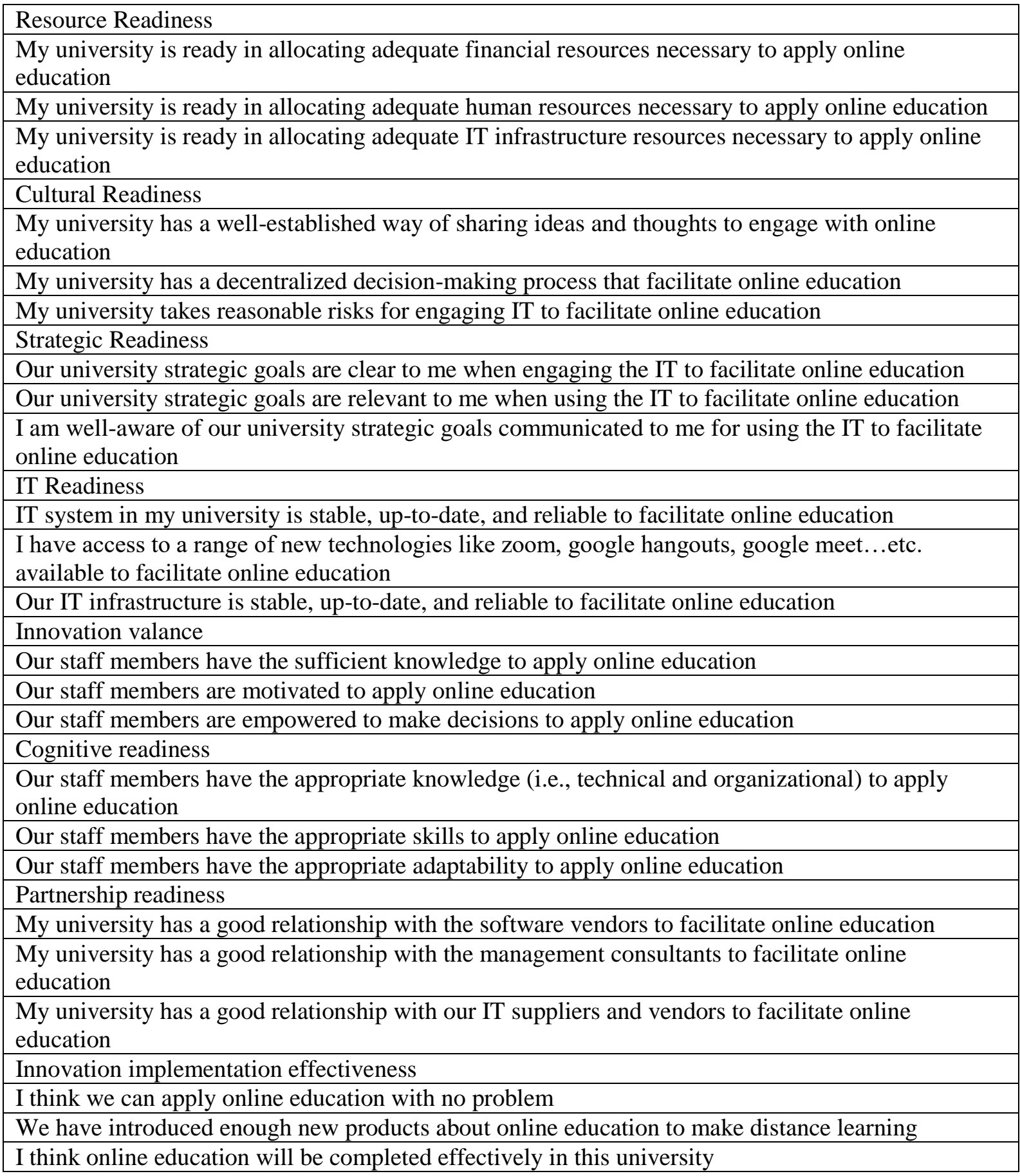

